\section{ANNALS OF THE UNIVERSITY OF CRAIOVA}

$\begin{aligned} \text { Series: } & \checkmark \text { Biology } \\ & \checkmark \text { Horticulture } \\ & \checkmark \text { Food products processing } \\ & \text { technology } \\ & \checkmark \text { Environmental engineering }\end{aligned}$

\author{
Vol. XXVI (LXII) - 2021
}

\title{
RESEARCH ON ENTOMOFAUNA FROM A POTATO CULTURE IN THE CĂLĂRAȘI, DOLJ AREA
}

\author{
Țucă Ovidiu Andrei ${ }^{1 *}$, Stan Cătălin ${ }^{1}$, Ciupeanu Călugăru Eleonora Daniela ${ }^{1}$, \\ ${ }^{1 *}$ University of Craiova, Faculty of Horticulture, Craiova \\ *Correspondence author.E-mail: ovidiu_tuca@hotmail.com
}

Keywords: potato, pests, beneficial species

\begin{abstract}
This paper presents the results of the research on the potato entomofauna, in the Călărași, Dolj area. that the most numerous pests belong to the order Coleóptera (14 species), followed by Ortoptera (4 species), Heteroptera (3 species), Hymenoptera (2 species), Lepidoptera (2 species) and Dermaptera (1 species). Of the total species identified (26 species), it was found that 15 species are harmful, six species are beneficial and two species are indifferent.
\end{abstract}

\section{INTRODUCTION}

Potatoes are a good source of energy, minerals, proteins, fats and vitamins (Ekin 2011; Drewnowski and Rehm 2013; King and Slavin 2013). Besides, potatoes are not just an important food source (Andre et al. 2014). They are also increasingly serving as feedstock for industrial products (Izmirlioglu and Demirci 2015; Jagatee et al. 2015). Therefore, unlike most other crops, potatoes have an unusually high range of utilisation possibilities, which makes their production even more attractive.

Potato production has been expanded in recent times and Solanum tuberosum is now one of the five most important food crops (Oerke, 2006). Insect pests in agricultural systems are one of the major causes of damage to crop production and storage (Thomas, 1999).

Being a native plant of the "new world", and due to its food value, industrial and agricultural potato was considered one of the most valuable acquisitions to mankind. It is estimated that in the mountains of northern coastal Peru, the potato is grown IV-VI through centuries $A D$, and the highland plateaus of central, around the year 1000 AD (Catelly T., 1988).

In Europe, the potato was first introduced in Spain (1565) using material from Peru. In new conditions spread quite quickly in culture, but only in 1573 represent trade item (Zamfirescu N. Velican V., 1964).

Recently, an estimated $37 \%$ of all crops are lost annually to pests (13\% to insects, $12 \%$ to pathogens, and $12 \%$ to weeds) despite the use of pesticidal and non-chemical controls (Pimentel 2018). In potato, insect pests and diseases pose continuous threat to crop operations resulting in 40\% yield losses (Beddington 2010). A wide range of insect pests damage potatoes; potato tuber moth (Phthorimaea operculella Z.) among lepidopterans and Colorado potato beetle (Leptinotarsa decemlineata, Say) among coleopterans is by far the most widespread and damaging insect pests of potato (Visser 2005; Rondon 2010). 


\section{MATERIAL AND METHODS}

The study was conducted in 2020 during the months of April to September in a potato farm from Călărași (Dolj) area.

To determine the structure of the harmful and beneficial populations were made collection of material using various means and methods: directly by hand from plants or soil, soil surveys and soil surface collected with entomological net, visual inspection, collection with sticky traps for flying insects, analyzing samples with binocular magnifier glass directly in the field or laboratory (Stan et al. 2012).

In order to Determine the species there has been used the Panin's Identification Manual (1951) and Guide des coleopteres d' Europe (Gaetan du Chatenent, 1990.)

Collecting the biological material has been made every two weeks, after that the entomological material was analyzed, identified and taxonomic classified. For as little impact on the ecosystem we have preferred to capture images with the camera than to capture live specimens were subsequently removed from their natural environment.

\section{RESULTS AND DISCUSSIONS}

The studies were carried out during May and September 2020 in a potato farm in Călărași, Dolj County.

In 2020, the results regarding the structure of the entomofauna from a potato farm in the Călărați area, included the identification of 26 species belonging to the Insecta class.

The collected insects were systematically classified in 7 orders: Orthoptera 4 species, Heteroptera 3 species, Hymenoptera 2 species, Coleoptera 14 species, Lepidoptera 2 species, Dermaptera and Homoptera 1 species belonging to 18 families.

ORTHOPTERA, Family Tettigoniidae: Tettigonia viridissima L.; Family Gryllidae Gryllus desertus Pali.; Family. Acrididae: Dociostaurus maroccanus Thumb.

DERMAPTERA Leach., Family. Forficulidae: Forficula auricularia L.;

HETEROPTERA Latr., Family. Pentatomidae: Graphosoma lineatus L., Dolycoris baccarum L. ; Family.Coredidae: Coreus marginatus L.;

COLEOPTERA Linné Family Carabidae: Calosoma sycophanta L.; Family Elateridae: Agriotes lineatus L., Agriotes ustulatus Schall.; Family Coccinellidae: Coccinella 7 punctata L., Adalia bipunctata L.; Family Tenebrionidae: Opatrum sabulosum L.; Family Scarabeidae: Geotrupes spiniger Marsh., Oxythyrea funesta Poda, Polyphylla fullo L., Melolontha melolontha L., Anoxia orientalis Kryn.,; Family Chrysomelidae: Leptinotarsa decemlineata Say., Chrysomela menthastri L., Cassida nebulosa L.,

HYMENOPTERA Linné. Family Scoliidae: Scolia flavifrons Fabr.; Family Apidae: Bombus terrestris L.;

LEPIDOPTERA Linné. Family Gelechiidae Phtorimea operculella (Zeller); Family Nyphalidae Vanessa atalanta.

Table 1

Potato entomofauna from a culture in the Călărași, Dolj area

\begin{tabular}{|c|l|l|c|}
\hline Nr. & \multicolumn{1}{|c|}{ Species } & \multicolumn{1}{|c|}{ Family } & Order \\
\hline 1. & Tettigonia viridissima L. & Tettigoniidae & \multirow{2}{*}{ Orthoptera } \\
\cline { 1 - 3 } 2. & Gryllus desertus Pali. & Gryllidae & \\
\cline { 1 - 2 } 3. & Dociostaurus maroccanus Thumb. & Acrididae & \\
\hline 4. & Gryllotalpa gryllotalpa L. & Grylotalpidae & \\
\hline
\end{tabular}




\begin{tabular}{|c|c|c|c|}
\hline 5. & Forjicula auricularia L. & Forficulidae & Dermaptera \\
\hline 6. & Dolycoris baccarum L. & \multirow[t]{2}{*}{ Pentatomidae } & \multirow{2}{*}{ Heteroptera } \\
\hline 7. & Graphosoma lineatus L. & & \\
\hline 8. & Carabus cancellatus Illiger & \multirow[t]{3}{*}{ Carabidae } & \multirow[t]{14}{*}{ Coleoptera } \\
\hline 9. & Calosoma sycophanta L. & & \\
\hline 10. & Amara crenata Dejean & & \\
\hline 11. & Coccinella 7 punctata L. & \multirow{2}{*}{ Coccinelidae } & \\
\hline 12. & Adalia bipunctata L. & & \\
\hline 13. & Agriotes lineatus L. & \multirow[t]{2}{*}{ Elateridae } & \\
\hline 14. & Agriotes ustulatus Schall. & & \\
\hline 15. & Opatrum sabulosum L. & Tenebrionidae & \\
\hline 16. & Geotrupes spiniger Marsh. & Geotrupidae & \\
\hline 17. & Polyphylla fullo L. & \multirow{2}{*}{ Scarabeidae } & \\
\hline 18. & Melolontha melolontha $\mathrm{L}$. & & \\
\hline 19. & Leptinotarsa decemlineata Say. & \multirow[t]{3}{*}{ Chrysomelidae } & \\
\hline 20. & Chrysomela menthastri L. & & \\
\hline 21. & Cassida nebulosa L. & & \\
\hline 22. & Macrosiphum euphorbiae Th. & Aphididae & Homoptera \\
\hline 23. & Scolia flavifrons Fabr. & Scoliidae & \multirow{2}{*}{ Hymenoptera } \\
\hline 24. & Bombus terrestris L. & Apidae & \\
\hline 25. & Vanessa atalanta $\mathrm{L}$. & Nymphalidae & \multirow[t]{2}{*}{ Lepidoptera } \\
\hline 26. & Phthorimaea operculella Zeller & Gelechiidae & \\
\hline
\end{tabular}

\section{CONCLUSIONS}

From the analysis of recorded data, it results that the most species belong to the order Coleóptera (14 species), followed by Orthoptera (4 species), Heteroptera (3 species), Hymenoptera (2 species), Lepidoptera (2 species) and Dermaptera (1 species).

According to our data, of the total species identified (26 species), it was found that 15 species are harmful, five species are beneficial and three species are indifferent. Regarding the beneficial species four of them belong to Coleoptera order, a single one belong to Hymenoptera order.

The most representative families has been Carabidae and Chrysomelidae each with 3 species, followed by Pentatomidae, Coccinellidae and Elateridae with 2 species.

\section{REFERENCES}

Andre C.M., Legay S., lammarino C., Ziebel J., Guignard C, Larondelle Y, Hausman J-F., Evers D., Miranda L.M.. (2014) The potato in the human diet: a complex matrix with potential health benefits. Potato Res 57:201-214. https://doi.org/10.1007/s11540-015-9287-3

Beddington J. 2009. Food security: contributions from science to a new and greener revolution. Philos Trans $\mathrm{R}$ Soc Lond Biol Sci. 2010;365:61-71. doi: 10.1098/rstb.0201.

Catelly T., 1988 Cartoful - banalitate sau miracol?, Editura Ceres, București

Drewnowski A., Rehm C.D. 2013 Vegetable cost metrics show that potatoes and beans provide most nutrients per penny. PLoS One 8:e63277. https://doi.org/10.1371/journal.pone.0063277 . 
Ekin Z. 2011. Some analytical quality characteristics for evaluating the utilization and consumption of potato (Solanum tuberosum L.) tubers. Afr $\mathrm{J}$ Biotechnol 10:6001-6010.

Gaëtan du Chatenet, 1990. Guide des Coléopterés d'Europe. Délacrois et Niestlé, Paris.

Izmirlioglu G., Demirci A. 2015. Enhanced bio-ethanol production from industrial potato waste by statistical medium optimization. Int J Mol Sci 16:24490-24505. https://doi.org/10.3390/ijms161024490 .

Jagatee S., Behera S., Dash P.K., Sahoo S., Mohanty R.C. 2015. Bioprospecting starchy feedstocks for bioethanol production: a future perspective. JMRR 3:24-42.

King JC., Slavin J.L. 2013. White potatoes, human health, and dietary guidance. Adv Nutr. 4:393S-401S. https://doi.org/10.3945/an.112.003525. 31-43.

Oerke, E. C. 2006. Crop losses to pest: Centenary review. J. Agric. Sci., 144:

Panin I., 1951. Determinatorul Coleopterelor dăunătoare şi folositoare din R.P.R. Edit. De Stat, Bucureşti.

Pimentel D. 2018. Handbook of natural pesticides: methods. Boca Raton: CRC Press; Pests and their control; pp. 3-19.

Rondon SI. 2005. The potato tuberworm: a literature review of its biology, ecology, and control. Am J Potato Res. 2010;87:149-166. doi: 10.1007/s12230-0099123-x.

Stan C., Țucă O., Ștefănescu M., Ciupeanu Călugăru Eleonora Daniela, Roșca Camelia Aida. 2012. Harmful and beneficial species and the relationships Between them within the ecosystem Nicolae Romanescu park. Annales of the University of Craiova, vol. XVII (LIII): $825-831$.

Thomas, M. B. 1999. Ecological approaches and the development of "truly integrated" pest management. Proc. Nat. Acad. Sci. USA, 96: 5944-5951.

Visser D. 2005 Guide to potato pests and their natural enemies in South Africa. Pretoria: Arc-Roodeplaat Vegetable and Ornamental Plant Institute; p. 105.

Zamfirescu N., Velican. V.1964. Fitotehnie. Edit. Agro-Silvica. 